\title{
Development and Validation of an Analytical Method for Related Substances in N-acetyl-L-cysteine Effervescent Tablets by RP-HPLC
}

\author{
Elizabeth Mary Mathew ${ }^{1}$, Angadi Ravi ${ }^{2}$, Nalawade Rameshwar ${ }^{2}$, Moorkoth Sudheer ${ }^{1}$, Bhat \\ Krishnamurthy ${ }^{1}$
}

${ }^{1}$ Department of Pharmaceutical Quality Assurance, Manipal College of Pharmaceutical Sciences, Manipal University, Manipal, Karnataka -576104, INDIA.

${ }^{2}$ STEER Life India Pvt. Ltd, Peenya Industrial Area, Bengaluru, Karnataka-560058, INDIA.

\begin{abstract}
Background: The reported chromatographic methods for $\mathrm{N}$-acetyl cysteine [NAC] are reverse phase HPLC and ion pair chromatography [IPC] for related substances test in bulk and in formulations. No reported stability indicating methods for the estimation of related substances in NAC effervescent formulation was found in literature. Objective: The present work was aimed at developing a selective, sensitive and reproducible stability indicating high-performance liquid chromatographic method for the quantitative determination of known, unknown impurities, degradation impurities and processrelated impurities of NAC effervescent formulation. Method: A reversed phase ion pair chromatographic method was developed employing Cadenza C18 column as the

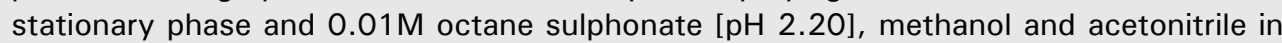
the ratio $90: 8: 2$ as the mobile phase. A gradient programme was followed with a run time of 55 minutes. $0.3 \mathrm{M}$ hydrochloric acid was selected as the optimum diluent. The performance of the method was validated according to the ICHO2R1 guidelines. Results: The method was found to be linear from 1.5 to $25 \mu \mathrm{g} / \mathrm{ml}$ for impurities $A, C$ and $D$ and from 2.0 to $25 \mu \mathrm{g} / \mathrm{ml}$ for impurity $B$. The official impurities $C$ and $D$ were mapped in all stress conditions. Additionally, impurity B was also seen in acidic conditions. Conclusion: The results from the study demonstrate that the method is suitable for evaluating the stability of NAC effervescent tablet.

Key words: N-acetyl cysteine, Reverse phase HPLC, Effervescent formulation, lon pair chromatography, Related substances, Validation.

Key message: An ion pair chromatographic method was developed for quantifying the related substances of $\mathrm{N}$-acetyl cysteine effervescent Tablets. Selection of diluent was an important variable in the method development.
\end{abstract}

\section{INTRODUCTION}

Acetyl cysteine also known as $\mathrm{N}$-acetylL-cysteine $[\mathrm{NAC}]$ is derived from cysteine by attaching an acetyl group to the amino group. It's basically a prodrug that is converted to cysteine and absorbed in the intestine into the blood stream. Cysteine is an important constituent of glutathione and hence acetyl cysteine aids in replenishing glutathione stores. The chief use of the drug is as a mucolytic agent as it helps loosen mucus in the airways due to emphysema, bronchitis, pneumonia and cystic fibrosis. It acts as an antidote of paracetamol poisoning by replenishing the glutathione reserves in the body. Glutathione acts as an antioxidant by conjugating the toxic metabolites of paracetamol poisoning. Other uses include in the treatment of HIV, chronic obstructive pulmonary disease, renal impairment, mild to moderate traumatic brain injury, idiopathic interstitial pulmonary fibrosis, colon polyps, adjunct in the treatment of Helicobacter pylori, contrast induced nephropathy, prophylactic of gentamycin-induced hearing loss in
Submission Date: 07-02-2017; Revision Date: 23-03-2017; Accepted Date: 13-07-2017

DOI: $10.5530 /$ ijper.51.4.93 Correspondence: Dr. Krishnamurthy Bhat, Department of Pharmaceutical Quality Assurance, Manipal College of Pharmaceutical Sciences, Manipal University, Manipal, Karnataka, INDIA.

Phone numbers: +919845801575

Facsimile numbers: +918202571998

E-mail:km.bhat@manipal. edu

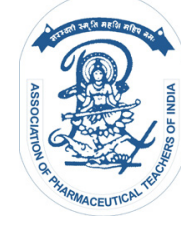

www.ijper.org 
patients on renal dialysis, treatment of infertility in patients with clomiphene-resistant polycystic ovary syndrome, neuropsychiatric and neurodegenerative disorders including cocaine, cannabis, smoking addictions, alzheimer's and parkinson's diseases, autism, compulsive and grooming disorders, schizophrenia, depression, and bipolar disorder. Recent studies have revealed that NAC inhibits muscle fatigue and can be used to enhance performance in exercise and endurance training. ${ }^{1-3}$ Analytical techniques like colorimetry, ${ }^{4,5}$ chemiluminiscence, ${ }^{6,7}$ electrochemical detection, ${ }^{8-15}$ flurimetry, ${ }^{16,17}$ turbidimetry and nephlometry, ${ }^{18}$ liquid chromatography tandem mass spectrometry, ${ }^{19-21-44}$ gas chromatography mass spectrometry, ${ }^{22,23}$ and capillary electrophoresis ${ }^{24-26}$ have been employed in literature for the quantification of acetyl cysteine. Acetyl cysteine has also been simultaneously quantified along with other drugs like clomiphene citrate, ${ }^{27}$ arginine,${ }^{28}$ and cefexime trihydrate. ${ }^{29}$ Stability testing studies of drugs in API and formulation provide evidence on the intrinsic stability of the molecule in response to environmental stress factors like temperature, humidity and light. This in turn helps in establishing shelf life for the drug product and recommended storage conditions. Forced degradation studies assist in developing a stability indicating method, they also offer vast knowledge on the possible degradation pathways and degradation products of the drug in bulk and formulation. ${ }^{30-33}$ The related substances [Figure 1] as described by the European pharmacopoeia and British pharmacopoeia are L-cystine [impurity A], L-cysteine [impurity B], N,N'-diacetylcystine [impurity C] and N,S diacetylcysteine [impurity D]. ${ }^{34,35}$ Among chromatographic methods literature reveals separation methods like reverse phase HPLC and ion pair chromatography for related substances test of NAC in bulk and drug products. ${ }^{34-44}$ Literature also reports expensive and less widely available techniques like LC-UV-MS ${ }^{44}$ and capillary electrophoresis-mass spectrometry ${ }^{25}$ for quantifying the related substances of acetyl cysteine. According to our findings, none of the currently available analytical methods is stability indicating. Based on the literature review there are no reported methods for the estimation of related substances in effervescent formulation of NAC by HPLC. The literature survey reveals that no reference exists for the quantitative determination of impurities by a stability-indicating HPLC method.

On screening the reported chromatographic methods for their suitability to the NAC effervescent formulation, the impurities L-cystine, L-cysteine and the placebo components were seen to elute at the same retention time. Hence, it was felt necessary to develop an accurate, selective and sensitive stability-indicating HPLC method
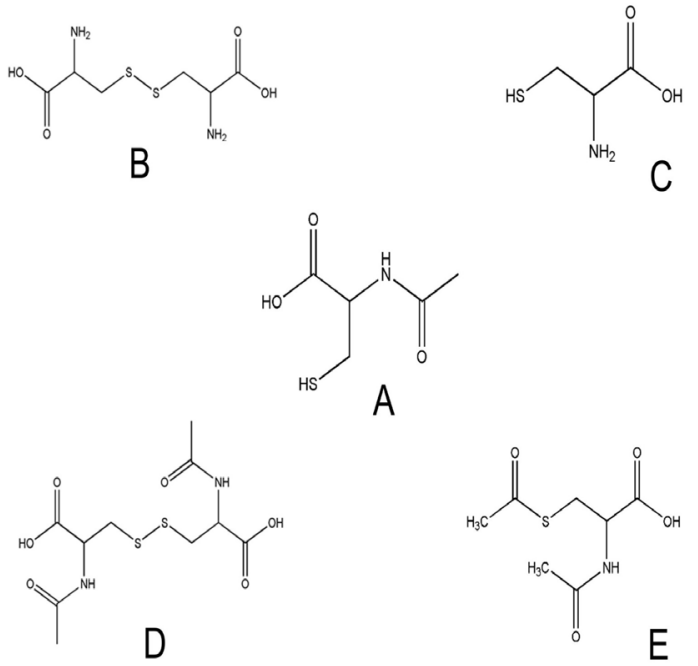

Figure 1: Chemical structures of[A] N-acetyl-L-cysteine, [B] L-cystine[Impurity A],[C]L-cysteine [Impurity B],[D] N,N'diacetyl -L-cystine [Impurity C] [E] N,S-diacetyl-L-cysteine [Impurity D].

for the determination of NAC and its related compounds. This method was successfully validated according to the International Conference on Harmonization [ICH] guideline Q2R1. ${ }^{45}$

\section{EXPERIMENTAL}

\section{Instrumentation}

The liquid chromatography method development was carried out using Agilent 1260 infinity series, which consisted of a pumping system, a thermostat column compartment, UV-DAD detector and an auto sampler [Agilent, USA]. Data were collected on a PC equipped with the Open-LAB Chem- station version C. 01.04 [35]. The method validation was carried out on Agilent 1260 and Shimadzu LC-20 prominence system. Shimadzu LC-20 prominence is equipped with a Shimadzu LC-20AD prominence pump, Shimadzu SPD-M10 diode array detector, Shimadzu SIL-20AC HT auto sampler and a Shimadzu CTO-10AS column compartment. The data were collected and analysed on a PC equipped with LC solutions version 1.25.

\section{Materials}

NAC[97\%], L-cystine [98\%], L-cysteine[97\%] were purchased from Sigma Aldrich, [Bangalore, India], N-acetyl cysteine impurity C CRS [61.9\%] and N-acetyl cysteine impurity D CRS were purchased as European reference standards. The in house HPLC water [Milli -Q] was used. Methanol [HPLC grade], acetonitrile [HPLC grade], octane-1-sulphonic acid sodium monohydrate 
[HPLC grade], orthophosphoric acid [AR], 37\% hydrochloric acid [AR] were purchased from Rankem [Mumbai, India]. The effervescent placebo was manufactured and supplied from the formulation facility of STEER Life India Pvt. Ltd. Bengaluru.

\section{Preparation of Solutions}

\section{Mobile phase:}

- Mobile phase A: 0.01M octane-1-sulphonic acid sodium monohydrate, $\mathrm{pH} 2.2$ adjusted with dilute ortho phosphoric acid.

- Mobile phase B: A mixture of $200 \mathrm{ml}$ of acetonitrile and $800 \mathrm{ml}$ of methanol.

\section{System suitability}

Following solutions were freshly prepared in $0.3 \mathrm{M}$ hydrochloric acid

- Resolution solution: An equal proportion mixture of $3000 \mu \mathrm{g} / \mathrm{ml} \mathrm{NAC}, 6 \mu \mathrm{g} / \mathrm{ml}$ impurity A, $6 \mu \mathrm{g} / \mathrm{ml}$ impurity B, $6 \mu \mathrm{g} / \mathrm{ml}$ impurity $\mathrm{C}$ and $6 \mu \mathrm{g} / \mathrm{ml}$ impurity D.

- Diluted standard solution: $10 \mu \mathrm{g} / \mathrm{ml}$ NAC.

- Diluent: $0.3 \mathrm{M}$ hydrochloric acid

\section{Forced Degradation}

- Acid degradation: API, placebo and placebo spiked with NAC were refluxed separately with $5 \mathrm{ml}$ of $1 \mathrm{M}$ hydrochloric acid for 15 mins at $80{ }^{\circ} \mathrm{C}$. The stressed samples ( $\mathrm{pH}$ 1.30-1.87) were cooled, neutralized with $1 \mathrm{M}$ sodium hydroxide and diluted with diluent to a final concentration of $3.0 \mathrm{mg} / \mathrm{ml}$ in case of API and placebo spiked with NAC

- Alkali degradation: API, placebo and placebo spiked with NAC were refluxed separately with $5 \mathrm{ml}$ of $1 \mathrm{M}$ sodium hydroxide for 15 minutes at $80^{\circ} \mathrm{C}$. The stressed samples ( $\mathrm{pH}$ 11.40-12.80) were cooled, neutralized with $1 \mathrm{M}$ hydrochloric acid and diluted with diluent for a final concentration of $3.0 \mathrm{mg} / \mathrm{ml}$ in case of API and placebo spiked with NAC.

- Peroxide degradation: API, placebo and placebo spiked with NAC were sonicated with $5 \mathrm{ml}$ of $0.3 \%$ $\mathrm{v} / \mathrm{v}$ hydrogen peroxide for 2 minutes. The stressed samples were cooled and diluted with diluent for a final concentration of $3.0 \mathrm{mg} / \mathrm{ml}$ in case of API and placebo spiked with NAC.

- Thermal degradation: API, placebo and placebo spiked with NAC were weighed separately in standard flasks, capped and kept in a hot air oven at $80^{\circ} \mathrm{C}$ for $2 \mathrm{hr}$. The stressed sample were cooled and dissolved with diluent for a final concentration of

\begin{tabular}{|c|c|c|}
\hline \multicolumn{2}{|c|}{ Table 1: Optimised gradient programme } \\
\hline Time[minutes] & $\begin{array}{c}\mathbf{0 . 0 1 M} \text { octane-1-sulphonic } \\
\text { acid } \\
\text { monohydrate sodium salt }\end{array}$ & $\begin{array}{c}\text { Methanol : } \\
\text { Acetonitrile } \\
{[\mathbf{8 0 : 2 0} \mathbf{~ v} \mathbf{v}]}\end{array}$ \\
\hline 0 & 90 & 10 \\
\hline 17 & 90 & 10 \\
\hline 20 & 70 & 30 \\
\hline 32 & 70 & 30 \\
\hline 35 & 90 & 10 \\
\hline 55 & 90 & 10 \\
\hline
\end{tabular}

$3.0 \mathrm{mg} / \mathrm{ml}$ in case of API and placebo spiked with NAC.

- Photolytic degradation: API, placebo and placebo spiked with NAC were kept in sunlight for 5 days. The stressed sample was then dissolved with diluent for a final concentration of $3.0 \mathrm{mg} / \mathrm{ml}$ in case of API and placebo spiked with NAC.

\section{RESULTS}

\section{Optimized chromatographic conditions}

The chromatographic separation was performed on a Cadenza $\mathrm{C}_{18}$ column $[150 \mathrm{~mm} \mathrm{X} 4.6 \mathrm{~mm}, 3 \mu$ ] from Almkat. The mobile phase consists of $0.01 \mathrm{M}$ octane -1-sulphonic acid sodium of $\mathrm{pH} 2.2$ and methanol: acetonitrile $[80: 20 \mathrm{v} / \mathrm{v}]$ in the organic phase. A gradient program was followed [Table 1] for 55 minutes. The flow rate was $1 \mathrm{ml} /$ minute and the sample injection volume was $10 \mu \mathrm{l}$. Column temperature was maintained at ambient. The detection wavelength was set at $210 \mathrm{~nm}$. $0.3 \mathrm{M}$ hydrochloric acid was used as the diluent.

\section{Forced degradation studies}

Forced degradation studies were performed as per Q1 $\mathrm{A}(\mathrm{R} 2)^{33}$ to assess the specificity and the stability indicating capacity of the method. Stressed drug substance, stressed placebo, and stressed placebo spiked with NAC were subjected to acid, alkali, peroxide [oxidative], thermal, photolytic [sunlight] and humidity with temperature conditions and injected into the HPLC. The specificity of the method, mass balance and the mapping of the official impurities in the stress conditions were carried out [Table 2 and Table 3]. There were no co-elution of impurities or placebo with the NAC peak and the official impurities peaks. The per cent degradation of NAC in the sample [placebo spiked with NAC] was seen to be in the range of $5-21 \%$ with the maximum degradation in photolytic condition. In comparison the degradation in API is from $12-22 \%$ with the maximum degradation seen in thermal conditions. Investigating the difference 
in the degradation pattern of API and formulation has been undertaken and the work is in progress.

\section{Method validation}

The method was validated to show compliance with regulatory requirements. The guideline as per the International Conference on harmonisation for validation of analytical procedures: text and methodology: Q2 [R1] was followed. ${ }^{45}$

System Suitability: System suitability test was carried out to verify that the analytical system was working as desired and can give precise and accurate results. Diluted standard and resolution solution were injected five times into the HPLC system. The results are displayed in Table 4. All the values were found to be within acceptable limits.

Specificity and forced degradation: The capability of the method to measure the analyte among excipients was evaluated by chromatographing the blank, placebo, resolution solution, and placebo spiked with resolution solution at specification level as per the optimized chromatographic conditions [Figure 2]. The peak purity of the NAC peak and its related substances were evaluated by the diode array detector and the peak was considered pure if the single point thre shold [SPT] was less than the peak purity index [PPI] [Figure 3]. The drug substance, placebo, and placebo spiked with NAC were exposed to forced degradation under acid, alkali, peroxide [oxidative], thermal, photolytic and humidity with temperature conditions. The resultant samples were

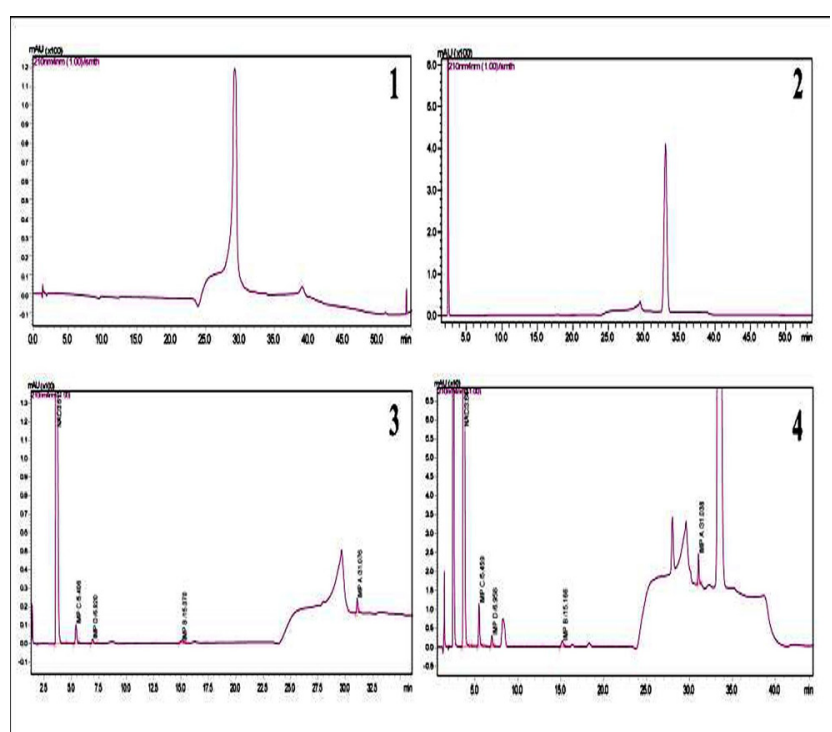

Figure 2: The chromatograms representing the specificity of the developed method: [1] Blank [2] Placebo solution [3] Resolution solution [4] Placebo spiked with NAC and known impurities.

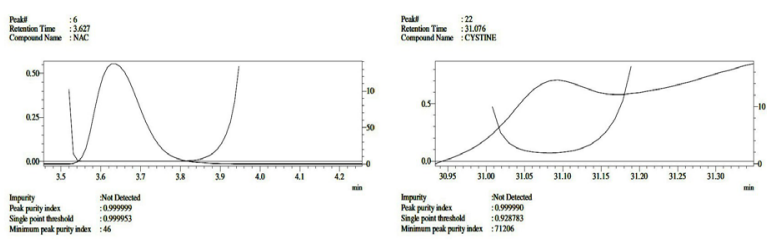

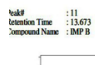

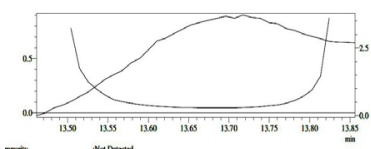

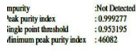

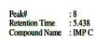

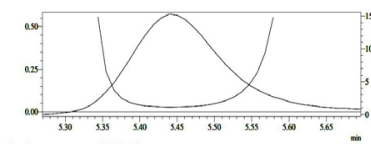

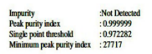

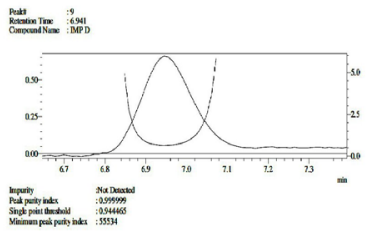

Figure 3: Peak purity curve of (A) N-acetyl-L-cysteine (B) L-cysteine [Impurity B] (C) L-cystine[Impurity A] (D) N,N'diacetyl -L-cystine [Impurity C] (E) N,S-diacetyl -L-cysteine [Impurity D].

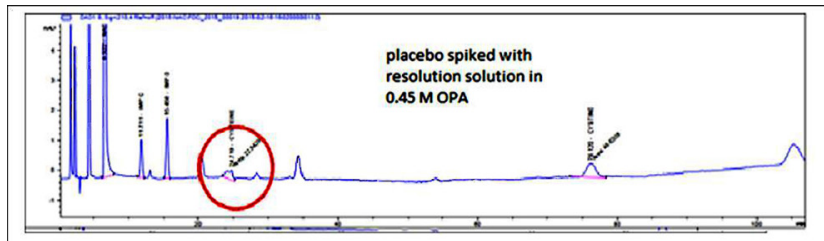

Figure 4: The chromatogram showing the additional peak co-eluting with L-cysteine when OPA was used as the diluent.

chromatographed on the HPLC after suitable treatment and dilution to establish the stability indicating power of the method [Figure 5]. The peak purity of the NAC peak was evaluated in all cases by the diode array detector and the peak was considered pure if the single point threshold[SPT]was less than the peak purity index [PPI] [Table 2 and Table 3].

Limit of detection [LOD] and limit of quantification [LOQ]: The LOQ and LOD were established by determining the signal to noise ratio. The experiment was executed by chromatographing separately samples of blank (diluent and placebo) and placebo spiked with impurities A, B, C, D at $0.75 \mu \mathrm{g} / \mathrm{ml}, 1 \mu \mathrm{g} / \mathrm{ml}, 1.5 \mu \mathrm{g} / \mathrm{ml}$ and $2 \mu \mathrm{g} / \mathrm{ml}$. Detection and quantification limits for NAC and impurities $\mathrm{A}, \mathrm{C}$ and D were found to be $0.75 \mu \mathrm{g} / \mathrm{ml}$ and $1.5 \mu \mathrm{g} / \mathrm{ml}$ respectively. For impurity B the acceptable LOD and LOQ results were obtained at $1 \mu \mathrm{g} / \mathrm{ml}$ and $2 \mu \mathrm{g} / \mathrm{ml}$ receptively.

Linearity and range: The linearity was determined by the linear regression analysis. The linearity was obtained for NAC from LOQ to $150 \% \mathrm{w} / \mathrm{w}$ sample concentration i.e. 1 to $4000 \mu \mathrm{g} / \mathrm{ml}$ and for impurities A, B, C and D from LOQ to $150 \% \mathrm{w} / \mathrm{w}$ of specification level, i.e. for $\mathrm{A}, \mathrm{C}, \mathrm{D}$ 
Table 2: Forced degradation and mapping of official impurities in NAC API

\begin{tabular}{|c|c|c|c|c|c|c|c|c|}
\hline Stress Condition & $\begin{array}{c}\% \\
\text { assay }\end{array}$ & $\begin{array}{c}\% \\
\text { degradation } \\
\text { of NAC }\end{array}$ & $\begin{array}{c}\% \\
\text { impurities }\end{array}$ & $\begin{array}{c}\text { Mass } \\
\text { balance }\end{array}$ & $\begin{array}{l}\text { Peak } \\
\text { purity } \\
\text { index }\end{array}$ & $\begin{array}{c}\text { Single } \\
\text { point } \\
\text { threshold }\end{array}$ & $\begin{array}{l}\text { Peak } \\
\text { purity } \\
\text { Result }\end{array}$ & $\begin{array}{c}\text { Remarks } \\
\text { (impurity } \\
\text { expressed } \\
\text { as \%w/w) }\end{array}$ \\
\hline Control & 95.86 & - & 3.50 & 99.36 & 0.9999 & 0.999936 & Pass & $\begin{array}{l}\text { C-2.47 } \\
\text { D-1.02 }\end{array}$ \\
\hline \multirow{2}{*}{ Acid Hydrolysis } & 73.5 & 22.3 & 28.72 & 108.0 & 1.0000 & 0.999946 & Pass & $\begin{array}{c}\text { C-2.0 } \\
\text { D-12.04 }\end{array}$ \\
\hline & \multicolumn{7}{|c|}{ UI: $2.53,13.05,23.04$ and 26.2 mins } & Ul-17.67 \\
\hline \multirow{2}{*}{ Alkali hydrolysis } & 79.8 & 16 & 13.64 & 98.4 & 0.9999 & 0.999952 & Pass & $\begin{array}{l}\text { C-5.74 } \\
\text { D-6.14 }\end{array}$ \\
\hline & \multicolumn{7}{|c|}{ UI: 2.7 and 3.2 mins } & Ul-5.02 \\
\hline \multirow{2}{*}{ Peroxide } & 83.8 & 12 & 15.82 & 98.6 & 0.9999 & 0.9952 & Pass & \multirow{2}{*}{$\begin{array}{l}\text { C-10.15 } \\
\text { D-1.06 } \\
\text { UI-3.38 }\end{array}$} \\
\hline & \multicolumn{7}{|c|}{ UI: 13.29and $26.7 \mathrm{mins}$} & \\
\hline \multirow{2}{*}{ Heat } & 65.4 & 30.4 & 31.83 & 97.3 & 1.0000 & 0.99999 & Pass & \multirow{2}{*}{$\begin{array}{l}\text { C-7.85 } \\
\text { D-6.3 }\end{array}$} \\
\hline & \multicolumn{7}{|c|}{ UI: $13.29,14.77$ and 26.77 mins } & \\
\hline \multirow{2}{*}{$\mathrm{H} / \mathrm{T}$} & 83.8 & 12 & 17.21 & 100.7 & 0.999999 & 0.999952 & Pass & \multirow{2}{*}{$\begin{array}{l}\text { C-10.64 } \\
\text { D-20.79 } \\
\text { UI-0.39 }\end{array}$} \\
\hline & \multicolumn{7}{|c|}{ UI: $13.92,26.4,27.6$ and $28.21 \mathrm{mins}$} & \\
\hline \multirow[t]{2}{*}{ Photolytic } & 83.2 & 12.6 & 18.43 & 101.7 & 1 & 0.999996 & Pass & \multirow{2}{*}{$\begin{array}{c}\text { C-6.37 } \\
\text { D-11.72 } \\
\text { UI-0.34 }\end{array}$} \\
\hline & \multicolumn{7}{|c|}{ UI: $4.39,6.1,6.38,6.6,19.27,26.35$ and $50.24 \mathrm{mins}$} & \\
\hline
\end{tabular}

B-impurity $B, C$-impurity $C, D$-impurity $D, U I$-Unknown impurities, $\mathrm{H} / \mathrm{T}$-humidity with temperature

\section{Table 3: Forced degradation and mapping of official impurities in effervescent formulation}

\begin{tabular}{|c|c|c|c|c|c|c|c|c|}
\hline $\begin{array}{l}\text { Stress } \\
\text { Condition }\end{array}$ & $\%$ assay & $\begin{array}{l}\% \text { degrada- } \\
\text { tion of NAC }\end{array}$ & $\begin{array}{c}\% \\
\text { Impurities }\end{array}$ & $\begin{array}{c}\text { Mass } \\
\text { balance }\end{array}$ & $\begin{array}{l}\text { Peak purity } \\
\text { index }\end{array}$ & $\begin{array}{l}\text { Single point } \\
\text { threshold }\end{array}$ & $\begin{array}{l}\text { Peak purity } \\
\text { result }\end{array}$ & $\begin{array}{c}\text { Remarks } \\
\text { [impurity } \\
\text { expressed as } \\
\% w / w]\end{array}$ \\
\hline Control & 96.9 & - & 2.9 & 99.7 & 1.00000 & 0.99995 & Pass & $\begin{array}{l}\text { C-1.99 } \\
\text { D-0.88 }\end{array}$ \\
\hline \multirow[t]{2}{*}{ Acid } & 84.9 & 12 & 7.0 & 96.0 & 0.99998 & 0.99995 & Pass & \multirow{2}{*}{$\begin{array}{l}\text { C-4.13,D-3.81 } \\
\text { B-0.265U-3.19 }\end{array}$} \\
\hline & \multicolumn{7}{|c|}{ U I- $13.97,14.53,26.29,53.29$ and $53.4 \mathrm{mins}$} & \\
\hline \multirow{2}{*}{$\begin{array}{c}\text { Alkali } \\
\text { hydrolysis }\end{array}$} & 92.3 & 4.6 & 4.9 & 96.1 & 0.99999 & 0.99520 & Pass & \multirow{2}{*}{$\begin{array}{c}\text { C-1.5D-1.06 } \\
\text { U-1.07 }\end{array}$} \\
\hline & \multicolumn{7}{|c|}{ UI 4.2,11.37and $32.24 \mathrm{mins}$} & \\
\hline \multirow[t]{2}{*}{ Peroxide } & 91.4 & 5.5 & 11.2 & 102.6 & 0.99999 & 0.99991 & Pass & \multirow{2}{*}{$\begin{array}{c}\text { C-2.22 D-0.11 } \\
\text { U-0.88 }\end{array}$} \\
\hline & \multicolumn{7}{|c|}{ UI- $2.52,4.39,8.00,13.06,14.04,19.59$ and 26.11} & \\
\hline \multirow[t]{2}{*}{ Heat } & 85.1 & 11.8 & 16.2 & 101.4 & 0.99998 & 0.99995 & Pass & \multirow{2}{*}{$\begin{array}{l}\text { C-6.98,D-0.11 } \\
\text { B-0.24, U-9.13 }\end{array}$} \\
\hline & \multicolumn{7}{|c|}{ UI: $2.9,4.27,8.03,13.18,15.49$ and 26.7} & \\
\hline \multirow[t]{2}{*}{$\mathrm{H} / \mathrm{T}$} & 84.8 & 12.1 & 19.5 & 104.3 & 1.00000 & 0.99992 & Pass & \multirow{2}{*}{$\begin{array}{c}\text { C-9.8,D-6.2 } \\
\text { U-3.27 }\end{array}$} \\
\hline & \multicolumn{7}{|c|}{ UI: $6.92,13.75,23.2$ and $26.36 \mathrm{mins}$} & \\
\hline \multirow[t]{2}{*}{ Photolytic } & 75.6 & 21.3 & 22.9 & 98.5 & 0.99999 & 0.999953 & Pass & \multirow{2}{*}{$\begin{array}{c}\text { C-14.35,D-4.60 } \\
\text { U-3.89 }\end{array}$} \\
\hline & \multicolumn{7}{|c|}{$\mathrm{UI}-5.16,29.81,31.48,33.38,33.67,33.84,46.26$ and 54.09 mins } & \\
\hline
\end{tabular}

B-impurity $B, C$-impurity $C, D$-impurity $D$, UI-Unknown impurities, $\mathrm{H} / \mathrm{T}$ humidity with temperature 


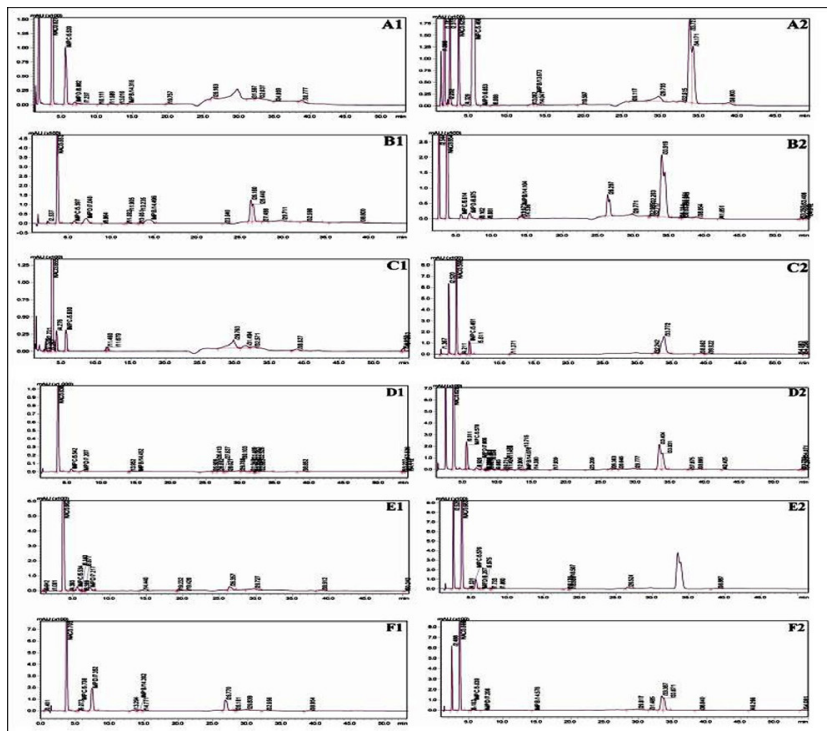

Figure 5: Forced degradation study:[A1] Peroxide degradation -API [NAC] [A2] Peroxide degradation-Effervescent tablet placebo spiked with NAC [B1] Acid Hydrolysis - API [NAC] [B2] Acid Hydrolysis - Effervescent tablet placebo spiked with NAC [C1]Alkali Hydrolysis - API [NAC] [C2] Alkali Hydrolysis - Effervescent tablet placebo spiked with NAC [D1] Humidity with temperature - API [NAC] [D2] Humidity with temperature - Effervescent tablet placebo spiked with NAC[E1] Photolytic [Sunlight] - API [NAC] [E2] Photolytic [Sunlight] - Effervescent tablet placebo spiked with NAC[F1] Thermal - API [NAC] [F2] Thermal - Effervescent tablet placebo spiked with NAC. it is 1.5 to $25 \mu \mathrm{g} / \mathrm{ml}$ and for impurity B it is 2.0 to $25 \mu \mathrm{g} / \mathrm{ml}$. In all the cases the regression coefficient was found to be not less than 0.99 . The details of the calibration graph i.e. slope; regression coefficient and Y-intercept are depicted Table 4.

Accuracy and Precision: Accuracy, method precision and intermediate precision were evaluated. The method precision was evaluated by spiking the effervescent placebo with impurities at LOQ level and at specification level [Table 4] and the \%RSD of six replicate injections were calculated. The intermediate precision was [Table 4] determined by spiking the placebo with impurities at specification level on different days and on different instruments and the \%RSD of five injections were calculated. In all the experiments the $\%$ RSD was found to be less than $10 \%$. Accuracy was performed as a single experiment at three different levels using three separate solutions by spiking the effervescent placebo at LOQ level, at specification level $[0.5 \% \mathrm{w} / \mathrm{w}]$ and at $150 \% \mathrm{w} / \mathrm{w}$ of specification level and the percent accuracy were calculated at all levels. (Table 4).

Robustness: The solution at specification level was used to evaluate the robustness of the method by making small but deliberate changes in flow rate $[ \pm 0.1 \mathrm{ml} / \mathrm{min}]$, dwell

\begin{tabular}{|c|c|c|c|c|c|c|c|}
\hline $\begin{array}{l}\text { Validation } \\
\text { parameter }\end{array}$ & Parameter & Levels & NAC & $\operatorname{Imp} A$ & $\operatorname{Imp} B$ & $\operatorname{Imp} C$ & Imp D \\
\hline \multirow{3}{*}{$\begin{array}{l}\text { System } \\
\text { suitability }\end{array}$} & $\begin{array}{c}R_{t} \\
\text { RRT } \\
T_{f} \text { for NAC }\end{array}$ & - & $\begin{array}{c}3.6 \\
- \\
1.17\end{array}$ & $\begin{array}{c}31.07 \\
8.63 \\
-\end{array}$ & $\begin{array}{c}15.07 \\
4.18 \\
- \\
\end{array}$ & $\begin{array}{c}5.41 \\
1.50 \\
-\end{array}$ & $\begin{array}{c}6.92 \\
1.92 \\
-\end{array}$ \\
\hline & $\begin{array}{c}\text { Rs between } \\
\text { impurity } C \text { and } D\end{array}$ & - & - & - & 6.57 & - & - \\
\hline & $\begin{array}{l}\% \text { RSD of area } \\
\text { response for } \\
\text { triplicate injection } \\
\text { of NAC in diluted } \\
\text { standard. }\end{array}$ & - & 0.70 & - & - & - & - \\
\hline Linearity & $\begin{array}{c}\text { Slope } \\
\text { Intercept } \\
\text { Regression } \\
\text { coefficient }\end{array}$ & $\begin{array}{l}- \\
- \\
-\end{array}$ & $\begin{array}{c}3319.2 \\
89766 \\
0.999\end{array}$ & $\begin{array}{c}3826.1 \\
115.6 \\
0.999\end{array}$ & $\begin{array}{c}1569.4 \\
238.39 \\
0.999\end{array}$ & $\begin{array}{c}4585 \\
622.66 \\
1.000\end{array}$ & $\begin{array}{c}6771.90 \\
264.13 \\
0.9998\end{array}$ \\
\hline $\begin{array}{l}\text { Method } \\
\text { precision } \\
(n=6)\end{array}$ & $\%$ RSD & $\begin{array}{c}\text { LOQ } \\
\text { Specification } \\
\text { level } \\
\text { Intermediate } \\
\text { precision }\end{array}$ & - & $\begin{array}{l}2.5 \\
2.3 \\
\text { 3. } 71\end{array}$ & $\begin{array}{l}4.2 \\
0.02 \\
3.12\end{array}$ & $\begin{array}{l}2.1 \\
0.50 \\
\text { 2. } 12\end{array}$ & $\begin{array}{l}4.4 \\
0.50 \\
\\
3.63\end{array}$ \\
\hline $\begin{array}{l}\text { Accuracy } \\
(n=3)\end{array}$ & $\begin{array}{c}\text { Mean \% recovered } \\
(\% \mathrm{RSD})\end{array}$ & $\begin{array}{c}\text { LOQ } \\
\text { Specification } \\
\text { level } \\
150 \% \mathrm{w} / \mathrm{w} \text { of } \\
\text { specification }\end{array}$ & - & $\begin{array}{c}104.73 \\
(2.2) \\
100.22 \\
(2.4) \\
\\
92.9 \\
(1.3)\end{array}$ & $\begin{array}{c}106.63 \\
(1.8) \\
100.06 \\
(3.9) \\
102.54 \\
(1.8)\end{array}$ & $\begin{array}{c}99.96 \\
(7.0) \\
\\
93.47 \\
(1.0) \\
\\
108.98 \\
(0.5)\end{array}$ & $\begin{array}{c}104.73 \\
(2.2) \\
\\
100.22 \\
(2.4) \\
92.90 \\
(1.3)\end{array}$ \\
\hline
\end{tabular}




\begin{tabular}{|c|c|c|c|c|c|c|c|c|c|}
\hline \multicolumn{2}{|c|}{$\begin{array}{c}\text { Robustness } \\
\text { parameter }\end{array}$} & Parameter & NAC & $\operatorname{Imp} A$ & $\operatorname{Imp} B$ & Imp C & Imp D & Cal $t$ value & $\begin{array}{l}\text { Table } t \\
\text { value }\end{array}$ \\
\hline \multirow{3}{*}{$\begin{array}{c}\text { Change in Flow } \\
\text { rate } \\
(\mathrm{ml} / \mathrm{min})\end{array}$} & 0.9 & \multirow{3}{*}{$\begin{array}{c}\text { Elution volume } \\
(\mathrm{ml})\end{array}$} & 3.60 & 29.18 & 15.28 & 5.42 & 8.16 & 0.045 & 2.355 \\
\hline & 1 & & 3.62 & 30.96 & 15.56 & 5.35 & 6.87 & - & - \\
\hline & 1.1 & & 3.69 & 33.44 & 16.61 & 5.55 & 8.23 & 0.156 & 2.015 \\
\hline \multirow{3}{*}{$\begin{array}{l}\text { Change in column } \\
\text { temperature }\end{array}$} & $20 \cdot \mathrm{C}$ & \multirow{3}{*}{$\begin{array}{l}\text { Retention time } \\
\quad \text { (mins) }\end{array}$} & 3.74 & 33.12 & 17.09 & 5.77 & 7.18 & 0.98 & 2.35 \\
\hline & $25^{\circ} \mathrm{C}$ & & 3.62 & 30.96 & 15.96 & 5.35 & 6.87 & - & - \\
\hline & $30 \cdot \mathrm{C}$ & & 3.5 & 31.20 & 14.94 & 5.02 & 6.52 & 0.84 & 2.35 \\
\hline \multirow[b]{2}{*}{ Dwell volume } & Agilent 1260 & \multirow{2}{*}{$\begin{array}{l}\text { Retention time } \\
\quad \text { (mins) }\end{array}$} & 3.56 & 28.46 & 15.80 & 5.61 & 7.18 & 0.4123 & 0.7078 \\
\hline & $\begin{array}{c}\text { Shimadzu LC- } \\
20 A D\end{array}$ & & 3.62 & 30.96 & 14.76 & 5.35 & 6.87 & 0.4123 & 0.7078 \\
\hline \multirow{3}{*}{$\mathrm{pH}$} & 2.0 & \multirow{3}{*}{ Tailing factor } & 1.14 & 1.01 & 1.00 & 1.14 & 1.02 & - & - \\
\hline & 2.2 & & 1.48 & 1.13 & 1.05 & 1.32 & 1.07 & 2.000 & 2.353 \\
\hline & 2.4 & & 1.41 & 1.01 & 1.03 & 0.95 & 1.00 & 0.400 & 2.353 \\
\hline \multirow{2}{*}{$\begin{array}{c}\text { Change in } \\
\text { organic }\end{array}$} & $80: 20$ & \multirow{2}{*}{ Tailing factor } & 1.14 & 1.01 & 1.00 & 1.14 & 1.02 & - & - \\
\hline & 88:12 & & 1.43 & 1.3 & 0.97 & 1.24 & 2.00 & 0.19 & 0.090 \\
\hline
\end{tabular}

volume[Agilent 1260 infinity and Shimadzu LC-20AD prominence], column oven temperature $\left[ \pm 5^{\circ} \mathrm{C}\right], \mathrm{pH}$ of the mobile phase [ \pm 0.2$]$ and per cent change in organic phase[88:12;methanol: ACN]. The student's t-test was used as the statistical tool to determine the statistical significance and in all the conditions there was no significant difference from the optimum conditions. The results are as displayed in Table 5.

\section{DISCUSSION}

The major objective of method development was to achieve separation between NAC and its related compounds. The hurdle was to obtain sufficient selectivity and resolution among structurally similar impurities, degradants and placebo components within a reasonable run time. For selecting the wavelength the UV absorption spectra of NAC and related compounds were studied and an absorption maximum was observed at $210 \mathrm{~nm}$. This wavelength was seen to be of high sensitivity for all related substances and a minimal difference in response factors was observed. For choosing the column, literature was scanned and the $\mathrm{C}_{18}$ column was chosen as the stationary phase. NAC and its impurities are highly polar in nature and for their optimum retention a column with a greater non polarity is required. ${ }^{46}$ Unsatisfactory results were observed on chromatographing the placebo and the resolution solution in the literature reported conditions owed to the impurities L-cysteine, L-cystine and the placebo components eluting near the void volume. The $\mathrm{pKa}$ of $\mathrm{NAC}$ are 3.24 [carboxylic acid moiety] and 9.52 [-SH group]. ${ }^{1,2}$ As per HendersonHesselbach equation above their pka acid moieties are known to exist in their ionised forms and elute early from the column, hence trials were performed at $\mathrm{pKa}$ -1 i.e.at $\mathrm{pH} 2.2 .{ }^{47}$ The impurities L-cysteine and L-cystine are polar in nature with their $\log \mathrm{P}$ being -2.5 and -5.08 respectively. ${ }^{1,2}$ For retaining such compounds on non-polar stationary phase mobile phase modifiers like ion pair reagents needs to be employed. $0.01 \mathrm{M}$ octane1 -sulphonic acid was employed to shift the impurities to a longer retention time. The anionic part [sulphate] of the ion pair reagent binds to the amino group of the impurities and the non-polar part binds to the non-polar chain on the column and hence increases the retention of the impurities. ${ }^{47}$ Literature was reviewed and methanol was seen to be the organic phase of choice. To further reduce the run time and maintain selectivity among structurally similar impurities, degradants and placebo components, 20 parts of acetonitrile was included as part of the organic phase. Acetonitrile is known to have greater elution strength than methanol. ${ }^{47}$ Ambient column temperature was maintained and a flow rate of $1 \mathrm{ml} /$ minute was used in all the method development trials. The isocratic mode of solvent delivery was followed initially with 90 parts of buffer and 10 parts of methanol, a run time of 75 minutes was observed. To further reduce the run time a gradient solvent delivery was seen imperative. Various gradients were tried and a final gradient [Table 1] with a run time of 55 minutes was optimized. During the course of the method development an interesting observation was the absence of L-cystine 
[impurity A] when the placebo spiked with the resolution solution was chromatographed. Further investigations revealed that the $\mathrm{pH}$ of the above solution was 3.31 which differ from mobile phase $\mathrm{pH}$ of 2.2. The effervescent couple was suspected to cause this change in $\mathrm{pH}$. Effervescent couple is a mixture of citric acid, sodium bicarbonate and sodium carbonate, which in presence of moisture instantaneously reacts and forms carbon dioxide and water. The evolved carbon dioxide dissolves in water to form carbonic acid which keeps the $\mathrm{pH}$ of the solution acidic. On storage the solution slowly loses its carbon dioxide and becomes alkaline. At this stage it became imperative to choose an appropriate diluent to recover the impurity L-cystine from the solution. Mineral acids like hydrochloric acid and orthophosphoric acid were screened to choose an optimum diluent. Various strengths of hydrochloric acid [from $0.1 \mathrm{M}$ to $0.3 \mathrm{M}]$ and orthophosphoric acid $[1 \% \mathrm{v} / \mathrm{v}$ to $5 \% \mathrm{v} / \mathrm{v}]$ were tested. The $\mathrm{pH}$ of the initial solution, $\mathrm{pH}$ immediately after the addition of the placebo and at 3 hours, 6 hours and 24 hours were measured. $0.3 \mathrm{M}$ Hydrochloric acid and $0.45 \mathrm{M}$ orthophosphoric acid solutions were the lowest molar concentration acid solutions which maintain the $\mathrm{pH}$ of the placebo solution less than or equal to 2.20 which corresponds to the mobile phase $\mathrm{pH}$. To choose the better diluent among $0.3 \mathrm{M}$ hydrochloric acid and $0.45 \mathrm{M}$ OPA, placebo spiked with the resolution solution were prepared in both the diluents and chromatographed in the optimized conditions. When 0.45M OPA was used as the diluent an additional peak was seen to co elute at the retention time of L-cysteine. $0.3 \mathrm{M}$ hydrochloric acid was selected to be the appropriate diluent as the resolution between the impurities were good and there was no interference from the placebo peaks. [Figure 2 and Figure 4]

Forced degradation studies provide knowledge on the possible degradation pathway and degradation products in API and effervescent formulation of NAC. NAC undergoes various transformations to form its known impurities and unknown impurities in different stress conditions [Table 2 and Table 3]. The main degradant in NAC are impurity $C$ and impurity $\mathrm{D}$ which are formed in all the stress conditions are due to the high susceptibility of the thiol moiety to oxidize and form disulphide. This impurity is also seen to form during storage of NAC. In addition to the impurity $\mathrm{C}$ and $\mathrm{D}$ in the acidic condition, impurity $\mathrm{B}$ is also seen to be formed this is due to the breaking of the $\mathrm{N}-\mathrm{C}$ bond in acidic conditions.

Impurity A is not seen in any of the stress conditions thereby confirming it to be a process impurity only and not a degradant. Heat is seen to cause maximum degradation of NAC and photolytic conditions in placebo spiked with NAC. The mass balance was found to be in the range of $96.5 \%$ to $103.5 \%$ in all stressed conditions of formulation stressed samples, thus proving the stability -indicating power of the method. Literature reports the formation of impurities $\mathrm{B}, \mathrm{C}$ and $\mathrm{D}$ on subjecting the aqueous solution, and cough syrup to various forced degradation conditions. ${ }^{39,40}$ From the forced degradation study conducted in our lab it is clear that known impurities $\mathrm{B}, \mathrm{C}$ and $\mathrm{D}$ are degradation impurities which need to be strictly monitored during stability studies.

\section{CONCLUSION}

In the present work a sensitive, specific and reproducible stability indicating HPLC method was established for the quantification of the degradants and process-related impurities of NAC effervescent formulation. The need for the development of an analytical method was identified because of the inadequate capacity of the reported HPLC methods in resolving among the known impurities and placebo peaks. The developed method shows good separation and resolution between the known impurity, degradation impurities and process-related impurities of NAC effervescent formulation. The $\mathrm{pH}$ was observed to be a crucial component in the method as the effervescent couple alters the $\mathrm{pH}$ of the diluent. The diluent $0.3 \mathrm{M}$ hydrochloric acid has proved to be efficient in arresting the $\mathrm{pH}$ change within $10 \%$ from the mobile phase $\mathrm{pH}$ and thus providing appropriate recovery for the impurities. The method has been validated as per ICH guidelines for specificity, linearity, accuracy, and precision, limit of quantitation and limit of detection. The results demonstrate that the method is suitable for evaluating the stability of NAC effervescent Tablet.

\section{ACKNOWLEDGEMENT}

The authors would like to thank Mr Indu Bhushan and all the scientists in STEER Life for their valuable support throughout the work. The Authors acknowledge Manipal University and Manipal College of Pharmaceutical Sciences for providing the infrastructure facility for carrying out this work. The authors also acknowledge the financial support provided by the DST-BIRAC scheme and FIST scheme.

\section{CONFLICT OF INTEREST}

The authors declare no conflicts of interest. 


\section{ABBREVIATION USED}

NAC: N-acetyl cysteine; IPC: Ion pair chromatography; ICH: International Conference on Harmonization; SPT: Single point threshold; PPI: Peak purity index; LOD: Limit of detection; LOQ: Limit of quantification; RSD: Relative standard deviation; ACN: Acetonitrile; UV- Ultraviolet; OPA: Orthophosphoric acid; AR: Analytical reagent; HPLC: High performance liquid chromatography; CRS: Certified refrence standard; LC-UV-MS: Liquid chromatography-Ultaviolet spectroscopy-mass spectrometry; HIV: Human immune deficiency virus; API: Active pharmaceutical ingredient.

\section{REFERENCES}

1. Drug Bank [2015]. Acetyl cysteine. Http://www.drugbank.ca/drugs/ DB06151\#references (accessed 15th march 2015).

2. Pubchem.[2015].Acetyl cysteine https://pubchem.ncbi.nlm.nih.gov/compound/ 12035\#section=Top (accessed on 16th march 2015)

3. Millea PJ. N-acetylcysteine: multiple clinical applications. American family physician. 2009;80(3):265-9. PMid:19621836.

4. Raggi MA, Cavrini V, Di PietraAM. Colorimetric determination of acetylcysteine, penicillamine, and mercaptopropionylglycine in pharmaceutical dosage forms. Journal of pharmaceutical sciences. 1982;71(12):1384-6. https://doi. org/10.1002/jps.2600711218; PMid:7153888.

5. Ogwu V, Cohen G. A simple colorimetric method for the simultaneous determination of $\mathrm{N}$-acetylcysteine and cysteine. Free Radical Biology and Medicine. 1998;25:362-4. https://doi.org/10.1016/S0891-5849(98)00024-0.

6. $\mathrm{Li} \mathrm{H}$, Du J. Sensitive chemiluminescence determination of three thiol compounds based on $\mathrm{Cu}$ (II)-catalyzing luminol reaction in the absence of an oxidant. Analytical Letters. 2009 Aug 21;42(13):2131-40. https://doi. org/10.1080/00032710903082754.

7. Samadi-Maybodi A, Akhoondi R. Trace analysis of N-acetyl-L-cysteine using luminol-H2O2 chemiluminescence system catalyzed by silver nanoparticles. Luminescence. 2015 Sep 1;30(6):775-9. https://doi.org/10.1002/bio.2819; PMid:25428294.

8. Foroughi MM, Beitollahi H, Tajik S, Akbari A, Hosseinzadeh R. Electrochemical determination of $\mathrm{N}$-acetylcysteine and folic acid in pharmaceutical and biological samples using a modified carbon nanotube paste electrode. Int. J. Electrochem. 2014 Dec 1;9:8407.

9. Shaidarova LG, Gedmina AV, Zhaldak ER, Chelnokova IA, Budnikov GK. Voltammetric Determination of Acetylcysteine in Drugs Using an Electrode Modified by an Osmium Hexacyanocobaltate Film. Pharmaceutical Chemistry Journal. 2014;47(12):670-4. https://doi.org/10.1007/s11094-014-1029-3.

10. Da Silva IS, Araújo MF, Ferreira HA, Varela JD, Tanaka SM, Tanaka AA, Angnes L. Quantification of N-acetylcysteine in pharmaceuticals using cobalt phthalocyanine modified graphite electrodes. Talanta. 2011;83: 1701-6. https://doi.org/10.1016/j.talanta.2010.11.070p; PMid:21238771.

11. Suarez WT, Marcolino LH, Fatibello-Filho O. Voltammetric determination of $\mathrm{N}$-acetylcysteine using a carbon paste electrode modified with copper (II) hexacyanoferrate (III). Microchemical journal. 2006;82(2):163-7. https://doi. org/10.1016/j.microc.2006.01.007.

12. Ensafi AA, Karimi-Maleh $H$, Mallakpour $S$, Hatami M. Simultaneous determination of $\mathrm{N}$-acetylcysteine and acetaminophen by voltammetric method using $\mathrm{N}$-(3, 4-dihydroxyphenethyl)-3, 5-dinitrobenzamide modified multiwall carbon nanotubes paste electrode. Sensors and Actuators B: Chemical. 2011;155(2):464-72. https://doi.org/10.1016/j.snb.2010.12.048.

13. Petrlova J, Mikelova R, Stejskal K, Kleckerova A, Zitka O, et al. Simultaneous determination of eight biologically active thiol compounds using gradient elution-liquid chromatography with Coul-Array detection. Journal of separation science. 2006;29(8):1166-73. https://doi.org/10.1002/ jssc.200500425; PMid:16830732.
14. Shahrokhian S, Kamalzadeh Z, Bezaatpour A, Boghaei DM. Differential pulse voltammetric determination of $\mathrm{N}$-acetylcysteine by the electrocatalytic oxidation at the surface of carbon nanotube-paste electrode modified with cobalt salophen complexes. Sensors and Actuators B: Chemical. 2008;133(2):599-606. https://doi.org/10.1016/j.snb.2008.03.034.

15. Houze P, Gamra S, Madelaine I, Bousquet B, Gourmel B. Simultaneous determination of total plasma glutathione, homocysteine, cysteinylglycine, and methionine by high-performance liquid chromatography with electrochemical detection. Journal of clinical laboratory analysis. 2001;15(3):144-53. https:// doi.org/10.1002/jcla.1018; PMid:11344530.

16. Ercal N, Oztezcan S, Hammond TC, Matthews RH, Spitz DR. Highperformance liquid chromatography assay for $\mathrm{N}$-acetylcysteine in biological samples following derivatization with $\mathrm{N}$-(1-pyrenyl) maleimide. Journal of Chromatography B: Biomedical Sciences and Applications. 1996;685(2):32934. https://doi.org/10.1016/S0378-4347(96)00196-X.

17. Johansson $M$, Lenngren $S$. Determination of cysteine, glutathione and $\mathrm{N}$-acetylcysteine in plasma by ion-pair reversed-phase liquid chromatography and post-column derivatization. Journal of Chromatography B: Biomedical Sciences and Applications.1988;432:65-74. https://doi.org/10.1016/S03784347(00)80634-9.

18. Santos VB, Guerreiro TB, Suarez WT, Faria RC, Fatibello-Filho O. Evaluation of turbidimetric and nephelometric techniques for analytical determination of n-acetylcysteine and thiamine in pharmaceutical formulations employing a lab-made portable microcontrolled turbidimeter and nephelometer. Journal of the Brazilian Chemical Society. 2011;22(10):1968-78. https://doi.org/10.1590/ S0103-50532011001000019.

19. Lu C, Liu G, Jia J, Gui Y, Liu Y, et al. Liquid chromatography tandem mass spectrometry method for determination of $\mathrm{N}$-acetylcysteine in human plasma using an isotope-labeled internal standard. Biomedical Chromatography. 2011;25(4):427-31. https://doi.org/10.1002/bmc.1465; PMid:21374646.

20. Celma C, Allue JA, Prunonosa J, Peraire C, Obach R. Determination of $\mathrm{N}$-acetylcysteine in human plasma by liquid chromatography coupled to tandem mass spectrometry. Journal of Chromatography A. 2000;870:13-22. https://doi.org/10.1016/S0021-9673(99)01252-2; https://doi.org/10.1016/ S0021-9673(99)01078-X.

21. Barricklow J, Ryder TF, Furlong MT. Quantitative interference by cysteine and $\mathrm{N}$-acetylcysteine metabolites during the LC-MS/MS bioanalysis of a small molecule. Drug metabolism letters. 2009;3(3):181-90. https://doi. org/10.2174/187231209789352148; PMid:19702543.

22. Longo A, Di Toro M, Galimberti C, CarenziA. Determination of N-acetylcysteine in human plasma by gas chromatography-mass spectrometry. Journal of Chromatography B: Biomedical Sciences and Applications. 1991;562:639-45. https://doi.org/10.1016/0378-4347(91)80614-I.

23. Hannested U, Sörbo B. Determination of 3-mercaptolactate, mercaptoacetate and $\mathrm{N}$-acetylcysteine in urine by gas chromatography. Clinica Chimica Acta. 1979;95(2):189-200. https://doi.org/10.1016/0009-8981(79)90359-0.

24. Dette $\mathrm{C}$, Wätzig $\mathrm{H}$. Separation of enantiomers of $\mathrm{N}$-acetylcysteine by capillary electrophoresis after derivatization by o-phthaldialdehyde. Electrophoresis. 1994;15(1):763-8. https://doi.org/10.1002/elps.11501501106; PMid:7982397.

25. Jaworska M, Szulińska G, Wilk M, Tautt J. Capillary electrophoretic separation of $\mathrm{N}$-acetylcysteine and its impurities as a method for quality control of pharmaceuticals. Journal of Chromatography A. 1999;853(1):479-85. https://doi.org/10.1016/S0021-9673(99)00727-X.

26. Zinellu A, Sotgia S, Scanu B, Usai MF, Fois AG, et al. Simultaneous detection of $\mathrm{N}$-acetyl-I-cysteine and physiological low molecular mass thiols in plasma by capillary electrophoresis. Amino Acids. 2009;37(2):395. https://doi. org/10.1007/s00726-008-0167-x; PMid:18695935.

27. Kumar $\mathrm{CH}$, Uma $\mathrm{G}$, Arcot $\mathrm{S}$. Method development and validation for simultaneous assessment of clomiphene citrate and n-acetyl cysteine in mixed tablet dosage form by RP-UPLC. World journal of pharmacy and pharmaceutical sciences.2014:3: 1773-1780

28. Jyothi NN, Pasha SI. Development and Validation of a New Rp-Hplc Method For Simultaneous Estimation of N-Acetyl cysteine And L-Arginine In Combined Dosage form. Oriental Journal of Chemistry. 2014;30(3):1371-8. https://doi.org/10.13005/ojc/300357.

29. Dabir J, Mathew EM, Moorkoth S. Analytical Method Development and Validation of RP-HPLC Method for Simultaneous Estimation of $\mathrm{N}$-acetyl cysteine and Cefexime from its Fixed Dose Combination. Research Journal 
of Pharmacy and Technology. 2016;9:835-42. https://doi.org/10.5958/0974360X.2016.00158.X.

30. Blessy MR, Patel RD, Prajapati PN, Agrawal YK. Development of forced degradation and stability indicating studies of drugs-A review. Journal of Pharmaceutical Analysis. 2014;4:159-65. https://doi.org/10.1016/j. jpha.2013.09.003.

31. Bakshi M, Singh S. Development of validated stability-indicating assay methods - critical review. Journal of pharmaceutical and biomedical analysis. 2002;28(6):1011-40. https://doi.org/10.1016/S0731-7085(02)00047-X.

32. Singh S, Bakshi M. Stress test to determine inherent stability of drugs. Pharm Technol. 2000;4:1-4

33. $\mathrm{ICH}$, Stability Testing of New Drug Substances and Products. International Conference on Harmonisation, IFPMA, Geneva, 2000, p. 13.

34. British Pharmacopoeia, $1 \mathrm{Vol}$. London : Medicines and Health Care products regulatory agency ; 2008:52-53

35. European Pharmacopoeia Commission. European Pharmacopoeia, 5 ed. Strasbourg: European Directorate for the quality of medicines and health care ; 2013:912,1211

36. Japanese Pharmacopoeia, 16 ed. Japan: Ministry of Health, Labour and Welfare. 2014:322-323

37. United States Pharmacopoeia, 29 ed. Rockville : United states Pharmacopoeial Convention. 2006;31(3):726

38. Sana S, Rajania A, Sumedhab N, Pravin P, Shripad N. Development and Validation of RP-HPLC Method for the Estimation of N-Acetylcysteinein Wet Cough Syrup. Int J Drug Dev Res. 2012;4:284-293.

39. Farquhar J, Finlay G, Ford PA and Martin-Smith M. A reversed-phase high-performance liquid chromatographic assay for the determination of $\mathrm{N}$-acetylcysteine in aqueous formulation. Journal of Pharmaceutical

\section{PICTORIAL ABSTRACT}

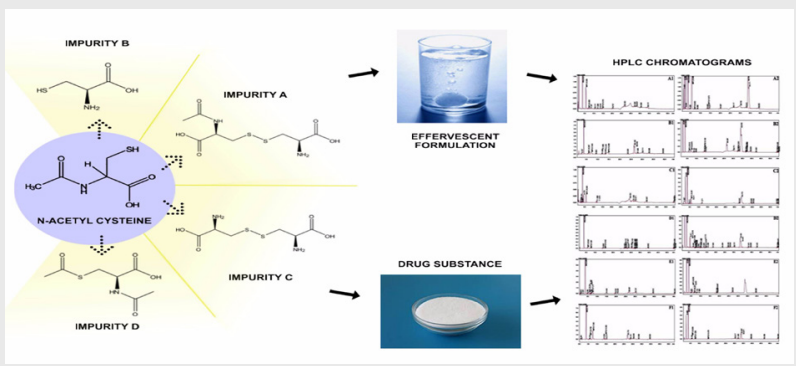

About Authors

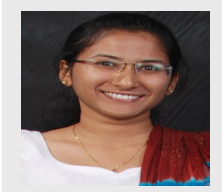

Ms Elizabeth Mary Mathew: Is currently pursuing her PhD since 2015 in Manipal college of Pharmaceutical sciences, Manipal University.

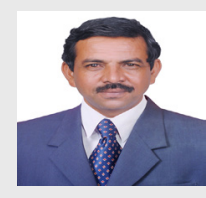

Dr. Krishnamurthy Bhat: Has a primary research interest in analytical method development and validation for new drugs and new methods for existing drugs. He is also an avid follower of drug regulations of important countries and does some research on the evolution of comparison of these regulations. Crystal engineering and formulation modifications as tools for improving bio-availability of drugs are another area where Dr. Bhat is actively researching. His work has been published in journals of repute. He is also a reviewer for few journals and expert committee members for various universities across the country.

Cite this article: Elizabeth MM, Ravi A, Rameshwar N, Sudheer M, Krishnamurthy B. Development and validation of an analytical method for related substances in N-acetyl-L-cysteine effervescent Tablets by RP-HPLC. Indian J of Pharmaceutical Education and Research. 2017;51(4):626-35. 